DOI

\title{
ОРГАНІЗАЦІЯ НАВЧАЛЬНОГО ПРОЦЕСУ ВИКЛАДАННЯ ДИСЦИПЛІН “МЕДИЧНА ХІМІЯ” ТА “БІООРГАНІЧНА ХІМІЯ” ДЛЯ ІНОЗЕМНИХ СТУДЕНТІВ І КУРСУ МЕДИЧНИХ ТА СТОМАТОЛОГІЧНОГО ФАКУЛЬТЕТІВ ЗА УМОВ КРЕДИТНО- ТРАНСФЕРНОЇ СИСТЕМИ НАВЧАННЯ
}

\author{
О. З. Бразалук, Г. С. Маслак, Л. Ф. Серебритська, Н. М. Черноусова \\ ДЗ “Дніпропетровська медична академія МОЗ Украӥни”
}

\section{ORGANISATION OF EDUCATIONAL PROCESS OF MEDICAL CHEMISTRY AND BIO-ORGANIC CHEMISTRY FOR FOREIGN STUDENTS OF THE I-ST COURSE OF MEDICAL AND STOMATOLOGY FACULTIES ACCORDING TO THE CREDIT-TRANSFER SYSTEM}

\author{
O. Z. Brazaluk, H. S. Maslak, L. F. Serebrytska, N. M. Chernousova \\ SI "Dnipropetrovsk Medical Academy of MPH of Ukraine"
}

\begin{abstract}
У статті розглянуто принцип побудови навчального процесу викладання дисциплін “Медична хімія” та “Біоорганічна хімія” для іноземних студентів I курсу медичних та стоматологічного факультетів за умов кредитно-трансферної системи.
\end{abstract}

The article presents the principle of construction of education process of Medical Chemistry and Bioorganic Chemistry for students of the I-st course in Medical and Stomatology Faculties according to the principles of credit-transfer system.

Вступ. Впровадження в Українську освітню сферу Болонського процесу тісно пов’язано з отриманням якісної вищої освіти [1]. Підвищені вимоги до якості підготовки медиків привели до реформування медичної освіти в Україні та застосування Європейської кредитно-трансферної системи організації процесу навчання і оцінювання знань студентів [2-6].

Проблема якості підготовки є надзвичайно актуальною, особливо при навчанні іноземних студентів, які після здобуття вищої медичної освіти в Україні повинні довести конкурентоспроможність на ринку праці, коли повернуться у свої країни [7].

Реформування і удосконалення процесу підготовки майбутніх лікарів потребує створення оптимальних умов і прогресивних методів навчання та контролю знань.

Підвищення якості освіти іноземних студентів потребує комплексного підходу: підвищення педагогічної майстерності викладачів, забезпечення якісними навчально-методичними матеріалами, систематичної самостійної роботи студента та відповідальності за якість освіти, вимог до рівня знань, враховуючи, що однією з причин слабкого засвоєння матеріалу є мовний бар’єр.

Педагогічний такт викладача, пов'язаний з урахуванням особливостей іноземних студентів різних національностей, впливає на психіку студентів, сприяє посиленню уваги на лекціях та практичних заняттях, засвоєнню знань.

За сучасними умовами Болонської системи, велика увага приділяється самостійній роботі студентів. Організація самостійної роботи студентів першого курсу покладена на викладача через систему домашніх завдань, постановку проблемних запитань за певним розділом курсу, консультацій. Доцільним у кредитно-трансферній системі навчання $є$ розвиток міждисциплінарної інтеграції при вивченні дисциплін за весь строк навчання.

Важливою частиною навчального процесу $є$ контроль отриманих знань, який об'єднує традиційні форми контролю та тестовий контроль, який

() О. З. Бразалук, Г. С. Маслак, Л. Ф. Серебритська, Н. М. Черноусова 
є одним із найсучасніших і науково обгрунтованих методів контролю поточних і підсумкових знань студентів [8-10].

Основна частина. 3 метою удосконалення системи оцінювання навчальної діяльності студентів за останній рік прийнято ряд документів:

1. Інструкція щодо оцінювання навчальної діяльності студентів в умовах впровадження Європейської кредитно-трансферної системи організації навчального процесу, затверджена МОЗ України 15.04.2014 p.

2. МОН щодо скасування обов’язковості кредитно-модульної системи від 24.09.2014 р. у зв’язку 3 необгрунтовано завищеними вимогами щодо навчання супроводу навчального процесу. Основне завдання навчального процесу - отримання знань студентом, систематична робота студента протягом семестру та контроль засвоєння студентом навчальної дисципліни. Для студентів I курсу медичних вузів основними дисциплінами є анатомія, гістологія, медична хімія, біоорганічна хімія, біохімія, медична біологія та інші.

Медична та біоорганічна хімія є основою при вивченні біологічної хімії та наступних спеціальних і професійних дисциплін, що сприяє формуванню професійної компетенції у студентів. Сучасний висококомпетентний фахівець повинен бути освіченим, мати загальну та професійну культуру, бути здатним до самоосвіти та підвищення рівня знань у своїй галузі. Студенти мають не тільки оволодіти знаннями та практичними навичками, але й вміти розв’язувати задачі, переносити здобуту інформацію на інші дисципліни, які вивчаються на старших курсах.

Курс медичної хімії та біоорганічної хімії зберігає характер фундаментальної дисципліни, складає основу для розуміння структурнофункціональних закономірностей здорового та хворого організму, що враховується в біохімії та інших медико-біологічних дисциплінах. Використання міжпредметних зв’язків відіграє позитивну роль як для закріплення певних тем, так і для засвоєння найважливіших понять, що зустрічаються в різних курсах дисциплін.

Навчальний процес на кафедрі біохімії медичної та фармацевтичної хімії Дніпропетровської медичної академії при вивченні іноземними студентами І курсу медичної та біоорганічної хімії здійснюється за кредитно-трансферною системою з застосуванням затверджених програм для вищих профільних закладів освіти України III-IV рівнів акредитації спеціальностей “Лікувальна справа”, “Педіатрія”, “Медико-профілактична справа”, “Стоматологія”.

Медична хімія як навчальна дисципліна структурована на 1 модуль із 10 практичних занять для спеціальностей “Лікувальна справа”, “Педіатрія”, “Медико-профілактична справа”.

Змістові модулі містять:

1. Термодинамічні та кінетичні закономірності перебігу процесів. Хімія біогенних елементів. Комплексоутворення в біологічних рідинах. Кислотноосновні рівноваги в біологічних рідинах.

2. Електрохімія та електрохімічні методи дослідження у медицині. Фізико-хімія поверхневих явищ. Ліофобні та ліофільні дисперсні системи.

Біоорганічна хімія для цих спеціальностей розрахована на 1 модуль із 8 практичних занять.

Для спеціальності “Стоматологія” програма 3 курсу “Медична хімія”, “Біоорганічна хімія” розрахована на 1 модуль із 9 практичних занять по кожній навчальній дисципліні.

Біоорганічна хімія (змістовий модуль) містить теоретичні основи будови та реакційної здатності біоорганічних сполук вуглеводнів, карбонільних сполук, вуглеводів, амінокислот, білків, ліпідів, біологічно активних гетероциклічних сполук, нуклеозидів, нуклеотидів, нуклеїнових кислот.

Видами навчальної діяльності іноземних студентів I курсу згідно з навчальним планом є лекції, практичні заняття, самостійна робота студентів (СРС). Для студентів спеціальності “Лікувальна справа” заплановано 10 лекцій (20 годин) та 50 годин практичних занять 3 курсу “Медична хімія”, за спеціальністю “Стоматологія” - 5 лекцій (10 годин) та 40 годин практичних занять. 3 курсу “Біоорганічна хімія” для спеціальності “Лікувальна справа” заплановано 5 лекцій (10 годин) та 30 годин практичних занять, за спеціальністю “Стоматологія”5 лекцій (10 годин) та 40 годин практичних занять.

Якісна підготовка іноземних студентів можлива тільки при комплексному підході до організації навчального процесу з обов'язковим включенням лекційного циклу та аудиторних практичних занять, живому спілкуванні викладача зі студентами.

Тематичні плани лекцій, практичних занять та СРС забезпечують реалізацію в навчальному процесі всіх тем, які входять до складу модулів. Лекції, як і раніше, залишаються однією із провідних форм навчання у медичному вузі. Теми лекційного курсу розкривають мотиваційну функцію, методичну, виховну, інформаційну, стимулюючу з використанням таблиць, надають 
рекомендації щодо використання основних висновків за темами на практичних заняттях. Для студентів I курсу іноземного факультету найбільш підходить класична інформаційна лекція 3 обов’язковим складанням конспекту. Менш позитивні результати дає лекція-прес-конференція, бінарна лекція та інші. Лекції є основною для практичних занять, на яких проводиться контроль підготовки для освоєння практичних навичок. На лекціях студенти набувають знання на рівні ознайомлення, на практичних заняттях створюються найбільш сприятливі умови для оволодіння поняттями та закріплення знань на якісно новому рівні засвоєння навчального матеріалу. Завдання викладача при вивченні дисциплін - навчити майбутнього медика вміння планувати навчальну роботу, здобувати та проводити систематизацію знань і умінь. 3 метою організації та вивчення дисциплін “Медична хімія” та “Біоорганічна хімія” складені методичні розробки, які дозволяють студентам I курсу міжнародного факультету успішно засвоїти матеріал програми. Методичні розробки для самостійної роботи студентів містять орієнтовні питання для самопідготовки, формульний матеріал, приклади задач та їх розв’язання, питання для самостійного опрацювання у вигляді тестів, наближених до модульного контролю, необхідний довідковий матеріал (таблиці 3 константами). Запропонований “Робочий зошит” завдань для самостійної та аудиторної роботи студентів I курсу міжнародного факультету створює сприятливі умови для педагогічного стимулювання навчання.

Засвоєння знань завершується контролем і оцінюванням результатів навчання. Контроль рівня підготовки здійснюється з застосуванням таких засобів, як: опитування на занятті, перевірка домашніх завдань, тестовий контроль, проведення лабораторних досліджень з оцінкою їх результатів. Оцінювання тем, які виносяться на самостійне опрацювання, контролюється під час поточного контролю та підсумкового модульного контролю. Поточне тестування проводиться на аудиторних заняттях 3 метою коригування навчальної діяльності студентів. Систематичний контроль примушує студента ретельно готуватися до заняття. Тестовий контроль є ефективним, оскільки дає можливість охопити матеріал з усієї пройденої теми, розвиває вміння логічно мислити. Завдяки контролю встановлюється зворотний зв'язок на занятті. Підсумковий контроль засвоєння модулів 3 дисциплін “Медична хімія” та “Біоорганічна хімія” проводиться по їх завершенню з метою об’єктивної оцінки успішності студентів. До підсумкового модульного контролю допускаються студенти, які відпрацювали всі навчальні заняття та набрали кількість балів не менше за мінімальну (40 балів).

Підсумковий модульний контроль вважається зарахованим, якщо студент набрав не менше 50 балів за 200-бальною шкалою. Максимальна кількість балів, яку може набрати студент під час складання підсумкового модульного контролю, - 80 балів.

Оцінка успішності (складається з суми балів поточного та підсумкового модульного контролю) є рейтинговою і виставляється за 200-бальною шкалою. Бали 3 дисципліни конвертуються у традиційну 4-бальну шкалу.

На кафедрі біохімії, медичної та фармацевтичної хімії професорсько-викладацьким складом кафедри обговорювались питання існуючої системи оцінювання у порівнянні з Інструкцією від 15.04.2014 p.

Внесена пропозиція залишити критерії оцінки, встановлені раніше:

\begin{tabular}{|l|l|}
\hline $170-200$ балів & Оцінка “5” \\
\hline $140-169$ балів & Оцінка “4” \\
\hline Від 139 балів до мінімальної (90) & Оцінка “3” \\
\hline Нижче мінімальної кількості балів (‘90) & Оцінка “2” \\
\hline
\end{tabular}

Пропозиція 180-200 балів оцінка “відмінно” для студентів I курсу вважати завищеною у зв’язку 3 адаптацією першокурсників до навчальної діяльності у вищому навчальному закладі.

Висновок. Впровадження кредитно-трансферної системи в навчальний процес викладання для дисциплін “Медична хімія" та “Біоорганічна хімія” для іноземних студентів I курсу медичних та стоматологічних факультетів є позитивним, оскільки впливає на мотивацію навчання студентів, сприяє підвищенню їх активності в навчальному процесі та результативності навчання. Підготовка іноземних студентів вимагає застосування традиційних та нетрадиційних форм навчання. Комплексне оцінювання знань припускає модульне тестування, поточний контроль, оцінювання 
самостійної роботи, які націлені на кінцевий результат. Підвищення якості навчання потребує творчого підходу до організації навчального процесу, подальшого удосконалення процесу навчання та оцінення знань і особливо поєднання

\section{Список літератури}

1. Вища освіта України і Болонський процес : навч. посіб. / за ред. В. І. Кременя. - Тернопіль : Навчальна книга - Богдан, 2004. - 384 с.

2. Впровадження кредитно-трансферної системи організації навчального процесу у ВМ(Ф)НЗ України; результати, проблеми та перспективи : матеріали Всеукраїнської навчально-наукової конференції. - Тернопіль : ТДМУ, 2010. - 493 с.

3. Про напрямки удосконалення якості підготовки студентів / Г. В. Дзяк, Т. О. Перцева, Л. Ю. Науменко [та ін.] // Медична освіта. - 2010. - № 2. - С. 100-101.

4. Загричук Г. Я. Концептуальні підходи щодо покращення якості підготовки фахівців / Г. Я. Загричук, В. П. Марценюк // Медична освіта. - 2012. - № 4. C. 44 .

5. Модернізація вищої медичної освіти в контексті Болонської конвенції - ідея, мета, реалії / В. М. Мороз, Ю. Й. Гумінський, Л. В. Фоміна [та ін.] // Медична освіта. - 2012. - № 2. - С. 42-45.

6. Кредитно-трансферна система організацій навчального процесу у вищих медичних (фармацевтичному) на- контролю засвоєння навчального матеріалу на іспитах, заліках з підсумковим тестовим контролем. Якраз над цими питаннями на теперішній час працює колектив кафедри, що буде викладено в наступних публікаціях.

вчальних закладах України на новому етапі : матеріали Х ювілейної Всеукраїнської навчально-наукової конференції з міжнародною участю : у 2 ч., Тернопіль, 18-19 квітня 2013. - Тернопіль : ТДМУ, 2013. - Ч. 1. 634 с.; ч. 2. -702 с.

7. Досвід роботи щодо підвищення якості підготовки іноземних студенів / Г. В. Дзяк, Т. О. Перцева, Л. Ю. Науменко [та ін.] // Медична освіта. - 2014. - № 2. - С. 59.

8. Геряк С. М. Тестування як основа кредитнотрансферного контролю / С. М. Геряк, І. В. Корда, Н. І. Багній // Медична освіта. - 2010. - № 1. - С. 77-79.

9. Булах I. Є. Проблеми оцінювання знань студентів у контексті вимог Болонської декларації / I. Є. Булах, О. П. Волосовець, М. Р. Мруга // Медична освіта. 2011. - № 2. - С. 20-22.

10. Унгурян Л. М. Застосування тестової системи оцінки знань у навчальному процесі / Л. М. Унгурян, М. С. Образенко // Медична освіта. - 2011. - № 3. C. 20-22. 